\title{
Introduction: Opening Ordinary Jerusalem
}

\author{
Angelos Dalachanis and Vincent Lemire
}

Is Jerusalem an ordinary city? To understand its history, should we favor a local or global approach? The goal of this collective volume is to take a head-on approach to these two persistent questions, which have long stood as a hindrance to writing the city's history. Taking as a departure point the conceptual framework of Open Jerusalem, a project funded by the European Research Council (ERC), ${ }^{1}$ each contribution works in its own way to confront, and transcend, a double uncertainty. First, Jerusalem is an extraordinary city that can be understood only with the greatest possible use of the most ordinary tools of social, political and cultural historical research. Second, Jerusalem's local history can only be reconstructed by reference to archives often located in faraway places, including, among others, Addis Ababa, Amman, Athens, Berlin, Erevan, Istanbul, London, Madrid, Moscow, Rome, St. Petersburg, Sofia and Washington. In transforming this double contradiction into a creative analytical tension, the thirty-seven authors of this volume revisit the ordinary history of a "global city" from 1840 to 1940, a century that covers the later period of Ottoman rule and most of the Mandate years.

\section{New Objects}

This new approach has thematic consequences. The new history of Jerusalem, to which this volume aims to contribute, goes beyond a study of geopolitics and religion. Western historians have long concentrated on these dimensions: from the top of the Mount of Olives they observed what they had come to find, that is, a constellation of controversial holy places clustered together on an

1 The Open Jerusalem project (full title: "Opening Jerusalem Archives: For a Connected History of Citadinité in the Holy City, 1840-1940") is funded by the European Research Council (starting grant) from 2014 to 2019 and is based at the Paris-Est Marne-la-Vallée University in France. The project is directed by Vincent Lemire and run jointly with the researchers of the core team: Stéphane Ancel, Yasemin Avcı, Louise Corvasier, Leyla Dakhli, Angelos Dalachanis, Abdul-Hameed al-Kayyali, Falestin Naili, Yann Potin, Maria Chiara Rioli and Katerina Stathi. In addition, more than 50 other scholars from Europe, the Middle East, the United States and Canada have been involved in the project so far. For more information see: http://www .openjerusalem.org.

(C) ANGELOS DALACHANIS AND VINCENT LEMIRE, 2018 | DOI:10.1163/9789004375741_002 This is an open access chapter distributed under the terms of the prevailing CC-BY-NC-ND License at the time of publication. 
eternal battlefield. Here we choose to shed light on unexpected actors hidden in the blind spots of the city's history, too long ignored by an expanding historiography, which sometimes is unperceptive and preconceived. These actors include the printers of visiting cards, Ottoman officers in charge of fiscal censuses, angry city dwellers signing petitions in favor of modernizing the water supply system, epidemiologists fighting malaria, municipal civil servants looking to Beirut, Haifa and Nablus for inspiration, an Islamic court judge deciding a case pitting a Russian plaintiff against an Armenian defendant, an Arab parliamentarian in conversation with the creator of modern Hebrew, an orphanage built on and run along American standards, a musicianphotographer, and the engineers and investors behind an aborted tramway project. These ordinary episodes are brought to life by ordinary actors who were part of Jerusalem's extraordinary destiny. It is through a history told from below, through small, everyday stories, that the grand history of the city emerges with new colors.

\section{New Timeline}

Chronologically speaking, this new approach also has consequences. Though the transition from Ottoman rule (1516-1917) to the British Mandate (1917-48) has traditionally been considered a key turning point in the history of Palestine and Jerusalem, the majority of the volume's contributors do not consider the year 1917 to be useful in their analyses. ${ }^{2}$ Nor do the historians represented here take a strictly geopolitical approach. Making use of the chronological framework offered by the Open Jerusalem project, they chose to consider the period from 1840 to 1940 as a coherent historical sequence that is well-suited to the study of Jerusalem's history. The commitment to studying these hundred years is in itself a historiographical novelty. Indeed, seeing past the 1917 mark makes it possible to analyze long-term historical factors otherwise overlooked by the geopolitical watershed associated with that year. Between the vigorous demographic renewal and the arrival of the first European consulates in the 1840 s, on the one hand, and the rise of intercommunity conflict in the late 1930s, on the other, the 1840-1940 span becomes a seamless historical sequence. This hundred-year period saw the birth, maturity and ruin of a certain model of citadinité, understood here as the way in which city dwellers share urban space, in varying degrees of harmony or conflict.

2 Abigail Jacobson recently attempted to rethink the breaks and continuities between the Ottoman period and the British Mandate in From Empire to Empire: Jerusalem between Ottoman and British Rule (Syracuse: Syracuse University Press, 2011). 
This relative continuity is particularly evident when one examines the specific institutional structures that largely persisted even after the fall of the Ottoman Empire, and on which many of the authors chose to concentrate, such as the municipalities, the patriarchates (Greek Orthodox, Armenian, Latin), the Muslim awqāf, the Sephardic kolels, the Islamic courts and the Franciscan Custody. These entities - religious, political, cultural and economic - are proof of an institutional resilience that, through this day, have rendered the "key years" of Jerusalem's history $(1917,1947,1967)$ partly meaningless. Certain local political actors, and some of the important Jerusalem families, also contributed to creating continuity between the Ottoman period and the British Mandate. Finally, administrative practices and daily urban problems such as public health and hygiene, public order, patrimony and public spaces reinforce this chronological continuity and reduce the importance of the geopolitical marker of 1917.

\section{New Archives}

This new approach has its most significant consequences in the realm of methodology. The history that we set out to tell here is informed by unpublished archival materials and is, as a result, a collective history founded on collaboration as well as the confidence in the utility of a collective endeavor. It would be impossible for a single researcher to access and analyze documents in Amharic, Arabic, Armenian, English, French, German, Greek, Hebrew, Italian, Ottoman Turkish, Russian, Syriac, to name but a few. Indeed, almost every language connected to the three Abrahamic religions was spoken, written and archived in the "global city" of Jerusalem. In addition to linguistic obstacles, there are, in many cases, geopolitical challenges. These archives are not always public and immediately accessible. They are dispersed throughout the world and can often be consulted only after passing checkpoints and borders that not all researchers can cross. The trust of archival institutions was secured thanks to the Open Jerusalem project's founding ideas: focusing on the description of archives rather than on their digitization. This approach stands out from most digital humanities history projects, which have often confused accessibility and mass digitization. Open Jerusalem privileges the description, indexing and translation of archives, in the conviction that the mere uploading of tens of thousands of digitized pages with no accompanying description does not necessarily make information accessible. With this approach, information is not merely made visible, but searchable and findable. This new strategy is perhaps the only way to break down the barriers that still limit and challenge community historiographies. 
The contributions assembled here illustrate another methodological ambition of the Open Jerusalem project: archival release must not be understood only in quantitative terms, but also, and perhaps especially, in qualitative ones. Renewing the history of Jerusalem requires more than gaining access to a mass of documents. Our aim also is to renew the type of documentation mobilized and fashion the theoretical and practical tools needed to establish links between documents. The articles in the present volume embody this renewal of documentary typology, voluntarily putting aside the most accessible exogenous narrative sources (such as travel narratives), and focusing instead on internal administrative sources. Repetitive as they may be, and requiring extra analytical efforts, these are the only sources that allow for a thorough reexamination of the historical stereotypes of the city. Such documents include baptismal registers, tax registers, meeting minutes, technical reports, collective petitions, accounting documents, payroll records, quotes, invoices, engineering plans, personnel directories, municipal deliberations, lists of indigents who received assistance, judicial reports, offers of concessions, signs and posters. These archives of quotidian lives and daily administrative practices often tell us more about the urban history experienced by Jerusalem residents than external narratives, which are so often interspersed with religious discourse and ideological projections.

\section{Connected History}

In addition to unlocking previously inaccessible archives and revising the typology of the documents studied, the Open Jerusalem historians also attempt to establish links between the various documentary collections. This effort is intended to refine analyses by encouraging comparisons between the city's communities. From a practical perspective, it also means that more information is made available about each community. In Jerusalem more than anywhere else, interactions between communities - whether they be peaceful or conflictual - are strong and frequent. They are documented through correspondence, complaints and petitions, and more. Essential information about a specific community may thus be scattered across many diverse archival holdings, sometimes in multiple languages and in many countries. It is in this way that descriptions and indexes, translations and collaboration, take on primary importance.

For example, in order to document the history of the city's small Ethiopian community, for example, it is not enough to consult Amharic records in the Ethiopian Archbishop's Palace in Jerusalem or in Addis Ababa. Given the 
relationship of subordination and protection that the Ethiopians of Jerusalem established with the Great Powers in the Holy City, one must also visit the Italian archives in Rome, and the Russian and Ottoman archives, respectively, in St. Petersburg and Istanbul. The history of the Armenian community is also documented in the archives of the Greek Orthodox Patriarchate, but these archives are largely connected to the Russian archives because of the links between these two major Orthodox churches. The history of Jerusalem's Jewish communities is contained in the British consular archives in London, but also in the American archives in Washington. The examples go on, but all of them show that Jerusalem has always been an open city, open to all influences, interferences and appropriations, be they symbolic, textual, military or territorial. For the historians of the Open Jerusalem project and those participating in this volume, the question is not so much how to open a city that is closed to the outside as it is to deal with a city that is compartmentalized and burdened by internal fractures. In order to begin this process, we must first open pathways that can be used to allow researchers to proceed to make connections between separate documentary collections. This opening process is one of the essential objectives of this collective work. ${ }^{3}$

\section{From New Archives to New Narratives}

For the Open Jerusalem project, this volume marks a shift from the identification and collection of archives to their assembly and the synthesis of original narratives. This is not to suggest that the archival work has come to an end. On the contrary, the Open Jerusalem web platform (www.openjerusalem.org) already makes documentation accessible to interested researchers and will keep the project alive, even after the end of ERC funding in 2019. Our ambition, though, is to begin putting concrete meaning on the extensive and unique raw empirical material that exists; to do so, we needed to approach these archives with methodology and theory, with content and structure. Our ambition is to offer a pivotal contribution to the history of Jerusalem of the late Ottoman and Mandate periods, not only by being methodologically and theoretically innovative, but also by challenging well-established ideological narratives regarding the city.

Many of the volume's chapters were initially presented as original papers at a symposium at the Institute for Mediterranean Studies in Rethymno,

3 Vincent Lemire (ed.), Jérusalem: Histoire d'une ville-monde des origines à nos jours (Paris: Flammarion, 2016), available in Italian and forthcoming in Arabic and English. 
Greece, in May 2016. Amounting to much more than a simple symposium, this research meeting, held halfway through the Open Jerusalem project, sought to be a forum for the deepening of discussions and the opening of scholarly debates, based on contributions by academics specializing in Jerusalem and Palestine as well as urban historians specialized in other Ottoman cities and related topics. Our subsequent objective was not to publish the symposium proceedings, but to combine the papers with a number of new contributions to produce a coherent volume that privileges interconnectedness. Our effort to link dissimilar approaches is somewhat reflected in the various origins of the volume's thirty-seven contributors. The scholars represented here are mostly young academics, of diverse national, ethnic and religious backgrounds, who in a way mirror the global character of the city that was and still is Jerusalem.

From the very start, our intention was to underline the city's global quality through a comparative perspective and, wherever possible, by adopting a gaze from below. To this end, the archival dimension of the authors' methodological work and analysis has been crucial. Each contributor was asked to include in their chapters a presentation and description of the sources and archives that they used for their contribution. More generally, they were also asked to discuss the available sources and archives relating to their topic. Seeking a "chronological" history, we asked the scholars to extend time limits when necessary, to include and analyze turning points, changes, shifts and gaps along with various experiences or perceptions of time. We also suggested that they look for connections with other studies, research fields and communities in order to create links between the city's usually fragmented historical narratives. To privilege connection over fragmentation, we encouraged the authors to seek contact points within their complex documentary archipelago and to show the exchanges, interactions and, where evident, hybridization between different populations and traditions. Finally, we asked them to try to bridge their contributions with the other papers that were presented at the symposium. We challenged them to cross-reference their fellow scholars, both in terms of content or methodology, and in terms of comparison or contrast. Our ambition is to open new paths for interconnected historical work.

\section{Looking for Citadinité}

In devising a novel historical approach to Jerusalem, our aim has been to publish a collective work structured around topics and questions already raised by the Open Jerusalem project. First, there is the central concept of citadinité, which the authors were invited to discuss critically whenever possible in light 
of their own research. As most historical studies do for the period under scrutiny, this volume attempts to deconstruct nationalism, colonialism and imperialism as well as to propose a different analytical framework for the study of the city. The concept of citadinité offers such a novel framework since it overcomes the binary scheme of domination/subjugation and regards Jerusalem as an inclusive city.

The notion of citadinité, borrowed from the French vocabulary of geography and urban sociology, describes the dynamic identity relationship city dwellers have with each other and their urban environment. ${ }^{4}$ It is also close to the notion of "cityness" forged by Saskia Sassen to reflect on the ability of residents of global cities to "make a city" together. ${ }^{5}$ While the Open Jerusalem project borrows from historical geography, it also avails of the tools of urban anthropology. ${ }^{6}$ Here, a connected history of citadinité embraces the key notion of "urban citizenship," meaning the identity-forming ties which (individually or collectively) link residents to their city, its history, patrimony, monuments, landscapes and eminent historical figures. Such ties are imagined, manufactured, appropriated and maintained, just like the ties that national citizenship produces. ${ }^{7}$ The notion of citadinité is, therefore, crucial to the study of the history of mixed, imperial and divided cities, as it asks a fundamental question: in the face of religious barriers and projections of national identities, how do residents proceed to "make a city" anyway?

Citadinité is not a vague, abstract notion that hovers above the city; nor is it only a discursive category. It is to a city what nationality is to a country, and it is materialized in institutions, actors and practices. Revisiting Jerusalem through citadinité also means revisiting practices related to it such as urban policies and institutions (municipality, waqf, consulates, patriarchates, associations). Contrary to what historiographic tradition has long maintained, ${ }^{8}$ the notion of public space is not absent from Muslim cities, where it must be studied

4 Michel Lussault and Pierre Signoles, eds, La citadinité en questions (Tours: Urbama; University of Tours, 1996).

5 Saskia Sassen, "Cityness," in Urban Transformation, ed. Andreas Ruby and Ilka Ruby (Berlin: Ruby Press; Zurich: Holcim Foundation for Sustainable Construction, 2008).

6 Jeff Halper, "On the Way: The Transition of Jerusalem from a Ritual City to Colonial City (1800-1917)," Urban Anthropology 13, no. 1 (1984).

7 Benedict Anderson, Imagined Communities: Reflections on the Origins and Spread of Nationalism (New York: Verso, 1983).

8 Xavier de Planhol, Les fondements géographiques de l'histoire de l'Islam (Paris: Flamarrion, 1968). 
simultaneously on the municipal, judicial and imperial levels. ${ }^{9}$ The Ottoman administrative reforms (Tanzimat) of the 1840 os favored the emergence of institutions such as the municipality, which furthered a shared city identity transcending communitarian barriers. ${ }^{10}$ Work on citadinité needs to prioritize such institutions, to which other institutions, notions and concepts are strongly linked, such as public services (transport, hygiene, etc.), public order (police), public knowledge (printing houses, multilingualism), public charity (the poor and orphans) and public opinion (newspapers, petitions, press interviews and debates). These are but a few examples of the investigations, made possible by connections between documentary collections, undertaken in the volume. The contributors revisit these approaches to citadinité along with other notions and analytical categories that have been rarely linked to Jerusalem, such as gender relations and children's lives. Jerusalem offers an impressive potential for a connected history of citadinité. We hope that this effort to uncover further opportunities will continue even after the ERC funding of the Open Jerusalem project ends.

\section{Four Parts, Four Paths}

Apart from primary sources, the authors of the volume put to use local and national historiographies in many different languages and adopted a variety of angles to revisit the aforementioned objects and approaches in the twenty-six chapters of the volume, which are divided into four thematic parts. We invited four prominent colleagues (Gadi Algazi, Beshara Doumani, Edhem Eldem and Gudrun Krämer) to preface these four parts using their sometimes distant but also highly qualified and sensitive perspectives. We asked them to provide a global reflection on their respective part with a short preface and we appreciate their eagerness to do so.

The first part, "Opening the Archives, Revealing the City," is prefaced by Krämer. This part is mostly structured around the archival material recently discovered by the core team and other researchers associated with the project. The opening of these archives provides material proof of the Open Jerusalem project's aim to create new perspectives on citadinité and global entanglements. Doumani prefaces the second part, "Imperial Allegiances and Local recherche sur le Maghreb contemporain, 2002).

10 Vincent Lemire, Jerusalem 19oo: The Holy City in the Age of Possibilities, trans. Catherine Tihayni and Lys Ann Weiss (Chicago: University of Chicago Press, 2017). 
Authorities," which brings the city into the logics of imperial and local legitimacy through the analysis of agency and various institutions: municipalities, patriarchates, consulates and court records. Jerusalem has always been a city of schools, teaching and libraries. During the second half of the nineteenth century, there was an increase in the flow and exchange of knowledge in a process of hybridization that helped bring about a shared urbanity. ${ }^{11}$ In this respect, the third part, entitled "Cultural Networks, Public Knowledge," is devoted to this reality. With his preface, Eldem offers the perspective of an Ottoman historian. The entire volume proposes a relational ordinary history of the city through links and contacts among people whose narratives of exceptionality and exclusivity are widespread. This is true not only among Jews and Palestinians, but also among Greeks, Armenians and other communities. The fourth and final part, "Sharing the City: Contacts, Claims and Conflicts," is prefaced by Algazi. It shows that the relational history of Jerusalem has never been harmonious, nor has it been a constant battlefield. Our goal is not to deny the existence of antagonisms between communities or to paint an idyllic picture of a city at peace. However, current communitarian, religious and ethnic divisions may obscure or disorient our gaze to the past, either by overemphasizing conflicts between specific ethnic or religious groups or by downplaying differences between others. Here, we seek to go far beyond partisan politics to shed light on a complex and stunning city.

Finally, we would like to express our gratitude to all the authors of the volume for their collaboration. We heartily thank the Institute for Mediterranean Studies of the University of Crete for hosting the symposium, its then-director Christos Hadziiossif, and Katerina Stathi, who coorganized it with us. The support of the University Paris-Est Marne-la-Vallée, and especially of Gilles Roussel, Damien Lamberton, Caroline Trotot, Loïc Vaderloge, Geneviève BührerThierry, Frédéric Moret, Valérie Theis, Bertrand Alliot, Bastien Pincanon, Virginie Leroy and Virginie Dubos-Jan, has been continuous and salient since the beginning of the Open Jerusalem project. The English-language editors of the volume, Jill A. McCoy, Niamh Keady-Tabbal and Damian Mac Con Uladh, did a great job and collaborated firmly and smoothly with us and the contributors. Katelyn Chin, the acquisition editor of the Open Jerusalem series at Brill, has been helpful and always available to discuss issues regarding the series and this volume in particular. Last but not least, we would like to thank

11 Jürgen Habermas, The Structural Transformation of the Public Sphere: An Inquiry into a Category of Bourgeois Society, trans. Thomas Burger and Frederick Lawrence (Cambridge: MIT Press, 1989). 
the rest of the core team of the project, namely Stéphane Ancel, Yasemin Avcl, Louise Corvasier, Leyla Dakhli, Abdul-Hameed al-Kayyali, Falestin Naïli, Yann Potin, Maria Chiara Rioli and Katerina Stathi. Since 2014, we have shared this long Jerusalem adventure together, and all of you have been available to read the chapters of the volume and provide excellent feedback. 